\title{
Implementasi Secure Hash Algorithm-1 Untuk Pengamanan Data Dalam Library Pada Pemrograman Java
}

\author{
Komang Aryasa*1, Yesaya Tommy Paulus ${ }^{2}$ \\ ${ }^{1}$ Teknik Informatika STMIK Dipanegara Makassar \\ ${ }^{2}$ Sistem Informasi STMIK Dipanegara Makassar \\ E-mail: ${ }^{* 1}$ aryuh09@gmail.com, ${ }^{2}$ nov62003@yahoo.com
}

\begin{abstract}
Abstrak
Masalah Keamanan merupakan salah satu aspek penting dari sistem informasi. Begitu pentingnya nilai informasi menyebabkan seringkali informasi diinginkan oleh orang tertentu kemudian dapat memodifikasi informasi tersebut. Untuk dapat mengesahkan informasi yang didapatkan, maka harus dilakukan authentication pada informasi sehingga diketahui keaslian informasi. Dalam penelitian ini diimplementasikan suatu metode secure hash algorithm-1, sehingga penerima informasi dapat mengetahui adanya perubahan terhadap data penting yang diterima dari pihak lain. Metode ini mampu membangkitkan nilai hash dari sebuah string atau file. Dengan perubahan sekecil apapun pada informasi yang diterima, dapat diketahui keasliannya. Secure Hash Algorithm adalah fungsi hash yang bekerja satu arah, ini berarti pesan yang sudah diubah menjadi message digest tidak dapat dikembalikan menjadi pesan semula. Dua pesan yang berbeda akan selalu menghasilkan nilai hash yang berbeda pula. Hasil rancangan perangkat lunak ini dengan input panjang string yang berbeda akan menghasilkan output dengan panjang string tetap yaitu 160 bit, yang dapat dibuat dalam bentuk library pada pemrograman java sehingga dapat langsung digunakan untuk proses otentikasi dan keamanan data.
\end{abstract}

Kata Kunci - SHA-1, data security, java, hash

\begin{abstract}
Security problem is one of the important aspects of the information system. Once the importance of the value of information causes information is often desired by a particular person can then modify that information. To be able to certify that the information obtained, it must be done so that the authentication on the information known to the authenticity of the information. In this study implemented a method of secure hash algorithm-1, so that the recipient can know the information of changes to important data received from the other party. This method is able to generate a hash value from a string or file. With the slightest change to the information received, it is known authenticity. Secure Hash Algorithm is a hash function that works in one direction, this means that the message has been converted into a message digest can not be restored to its original message. Two different messages will always produce a different hash value. Software design results with different input string length would produce output with fixed string length is 160 bits, which can be made in the form of the Java programming library that can be directly used for authentication and data security.
\end{abstract}

Keywords - SHA-1, data security, java, hash 


\section{PENDAHULUAN}

Masalah keamanan merupakan salah satu aspek penting dari sebuah sistem informasi. Sayang sekali masalah keamanan ini sering kali kurang mendapat perhatian dari para pemilik dan pengelola sistem informasi. Seringkali masalah keamanan berada di urutan kedua, atau bahkan di urutan terakhir dalam daftar hal-hal yang dianggap penting. Apabila mengganggu performansi dari sistem, seringkali keamanan dikurangi atau ditiadakan. Sangat pentingnya nilai sebuah informasi menyebabkan seringkali informasi diinginkan hanya boleh diakses oleh orang-orang tertentu. Jatuhnya informasi ke tangan pihak lain (misalnya pihak lawan bisnis) dapat menimbulkan kerugian bagi pemilik informasi. Sebagai contoh, banyak informasi dalam sebuah perusahaan, oleh karenanya untuk dapat mengesahkan informasi yang didapatkan, maka harus dilakukan authentication pada informasi sehingga perusahaan dapat terhindar dari penipuan mengenai informasi tentang produk yang sedang dalam development, algoritma-algoritma dan teknik-teknik yang digunakan untuk menghasilkan produk tersebut. Untuk itu keamanan dari sistem informasi yang digunakan harus terjamin dalam batas yang dapat diterima. Usaha-usaha yang dapat dilakukan untuk menjaga keamanan dari sebuah sistem antara lain dengan membangun teknologi kriptografi (dengan enkripsi dan deskripsi). Kriptografi merupakan sebuah teknik mengubah sebuah plaintext menjadi sebuah ciphertext Di dalam kriptografi terdapat sebuah fungsi yang sesuai untuk aplikasi keamanan seperti otentikasi dan integritas pesan. Fungsi tersebut adalah fungsi hash[5,7].

Fungsi hash adalah sebuah fungsi yang menerima masukan string yang panjangnya sembarang dan mengkonversikannya menjadi string keluaran yang panjangnya tetap (fixed) dan umumnya jauh lebih kecil dibandingkan string semula. Fungsi hash satu arah (One way Hashing) adalah fungsi hash yang bekerja dalam satu arah, ini berarti pesan yang sudah diubah menjadi message digest tidak dapat lagi dikembalikan menjadi pesan semula. Dua pesan yang berbeda akan selalu menghasilkan nilai hash yang berbeda pula. Sehingga message digest dari sebuah string dapat dijadikan sebagai sebuah sidik jari.

Pokok permasalahan dalam penelitian ini adalah bagaimana mengimplementasikan algoritma SHA-1 kedalam bahasa pemrograman Java dan membentuk sebuah library dari kelaskelas yang telah dibuat sebelumnya. Dan Ruang lingkup penelitian dibatasi pada:

1. Implementasi eksperimen menggunakan bahasa pemrograman Java

2. Algoritma enkripsi yang digunakan adalah SHA-1 (Secure Hash Algorithm-1)

3. Library yang dibentuk adalah ber-ekstensi *.jar.

4. Input yang digunakan adalah sebuah string dengan panjang maksimum adalah $2^{64}$ bit.

5. Output yang dihasilkan adalah sebuah string dengan panjang tetap yaitu 160 bit.

6. Untuk dapat menguji library yang dibentuk, dibuatkan sebuah interface yang mana digunakan untuk memasukkan string dan akan menghasilkan sebuah message digest.

Tujuan penelitian ini adalah membuat sebuah library, pada pemrograman java dalam membuat sebuah message digest dari suatu string. Sehingga dapat langsung digunakan untuk otentikasi dan keamanan data.

\subsection{Fungsi Hash}

Sebuah fungsi hash (hash function atauhash algorithm) adalah suatu cara untuk menghasilkan sebuah digital "fingerprint" kecil dari sembarang data [1,2,3]. Fungsi ini memecahkan dan mencampurkan data untuk menghasilkan fingerprint yang sering disebut sebagai nilai hash (hash value). Nilai hash ini sering direpresentasikan dengan sebuah stringpendek dari huruf-huruf dan angka-angka yang kelihatan acak (berbentuk heksadesimal). Sebuah fungsi hash yang baik adalah suatu fungsi yang tidak (jarang) memiliki output nilai hash yang sama untuk input yang berbeda. 


\subsection{Fungsi Hash Satu Arah}

Fungsi hash satu arah (One-way hash) adalah fungsi hash yang bekerja dalam satu arah $[1,2,3]$. String yang telah diubah menjadi message digest tidak dapat lagi dikembalikan menjadi string semula. Dua string yang berbeda akan selalu menghasilkan nilai hash yang berbeda pula. Sifat-sifat dari fungsi hash satu arah adalah sebagai berikut :

1. Fungsi $H$ dapat diterapkan pada blok data berukuran apa saja.

2. $H$ menghasilkan nilai $(h)$ dengan panjang tetap (fixed-length output).

3. $H(x)$ mudah dihitung untuk setiap nilai $x$ yang diberikan.

4. Untuk setiap $h$ yang diberikan, tidak mungkin menemukan $x$ sehingga $H(x)=h$.

5. Untuk setiap $x$ yang diberikan, tidak mungkin mencari $y \neq x$ sedemikian sehingga $H(y)=H(\mathrm{x})$.

6. Secara komputasi tidak mungkin mencari pasangan $x$ dan $y$ sedemikan sehingga $H(x)=H(\mathrm{y})$

Fungsi hash adalah publik (tidak dirahasiakan), dan keamanannya terletak pada sifat satu arahnya itu. Skema fungsi hash ditunjukkan pada gambar 1 di bawah ini:

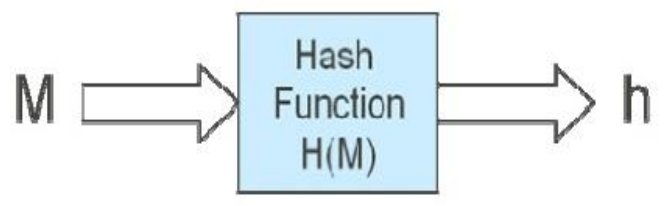

Gambar 1. Fungsi hash satu arah

\subsection{Secure Hash Algorithm (SHA)}

Secure Hash Algorithm (SHA) adalah fungsi hash satu arah yang dibuat olehNIST (National Institute of Standard and Technology) [1,2,3]. SHA dinyatakan sebagai standar fungsi hash satu arah. SHA dapat dianggap sebagai kelanjutan pendahulunya MD5 dan dapat dikatakan aman karena dirancang sedemikian rupa sehingga secara komputasi tidak mungkin menemukan string yang berkoresponden dengan message digest yang diberikan.

\subsection{Secure Hash Algorithm-1 (SHA-1)}

SHA-1 menerima masukan berupa string dengan ukuran maksimum $2^{64}$ bit. Untuk setiap string, SHA-1 akan menghasilkan keluaran sebanyak 160 bit dari string tersebut dan string keluaran itu disebut message digest. Panjang jarak message digest dapat berkisar antara 160 sampai 512 bit tergantung algoritmanya. Berdasarkan cirinya SHA-1 dapat digunakan dengan algoritma kriptografi lainnya seperti Digital Signature Algorithms atau dalam generasi angka yang acak (bits). SHA-1 dikatakan aman karena proses SHA-1 dihitung secara infisibel untuk mencari string yang sesuai untuk menghasilkan message digest atau dapat juga digunakan untuk mencari dua string yang berbeda yang akan menghasilkan message digest yang sama. Untuk SHA-1 ukuran blokstring -m bit- dapat ditentukan tergantung dari algoritmanya. Pada SHA-1 masing-masing blokstring mempunyai 512 bit dimana dapat dilakukan dengan 16 urutan sebesar 32 bit. SHA-1 digunakan untuk menghitung message digest pada string atau file data yang diberikan sebagai input. Tujuan pengisian string adalah untuk menghasilkan total dari string yang diisi menjadi perkalian dari 512 bits. Beberapa hal yang dilakukan dalam pengisian string:

a. Panjang dari string, $\mathrm{M}$ adalah $\mathrm{k}$ bits dimana panjang $\mathrm{k}<2^{64}$. Tambahkan bit "1" pada akhir string. Misalkan string yang asli adalah "01010000" maka setelah diisi menjadi “010100001". 
b. Tambahkan bit " 0 ", angka bit "0" tergantung dari panjang string. Misalnya :String asli yang merupakan bit string: abcde 0110000101100010011000110110010001100101.

Setelah langkah (a) dilakukan 0110000101100010011000110110010001100101.

Panjang $\mathrm{k}=40$ dan angka bit di atas adalah 41 dan 407 ditambah bit "0" $(448-(40+1)=$ 407). Kemudian diubah dalam hex:

$6162636465800000 \quad 00000000 \quad 00000000$

$00000000 \quad 00000000 \quad 00000000 \quad 00000000$

$00000000 \quad 00000000 \quad 00000000 \quad 00000000$

000000000000000

c. Untuk memperoleh 2 kata dari $\mathrm{k}$, angka bit dalam string asli yaitu jika $\mathrm{k}<2^{32}$ maka kata pertama adalah semua bit " 0 ". Maka gambaran dari 2 kata dari $\mathrm{k}=40$ dalam hex adalah 0000000000000028.

$61626364 \quad 65800000 \quad 00000000 \quad 00000000$

$00000000 \quad 00000000 \quad 0000000000000000$

$00000000 \quad 00000000 \quad 00000000 \quad 00000000$

00000000000000000000000000000028

SHA-1 menggunakan urutan fungsi logika yang dilambangkan dengan $\mathrm{f}_{0}, \mathrm{f}_{1}, \ldots, \mathrm{f}_{79}$. Untuk masing-masing $\mathrm{f}_{\mathrm{t}}$, dimana $0 \leq \mathrm{t}<79$ akan menghasilkan output sebanyak 32 bit. Fungsinya adalah sebagai berikut:

$$
f_{t}(B, C, D)= \begin{cases}(B \wedge C) \vee(\neg B \wedge D) & 0 \leq t \leq 19 \\ B \oplus C \oplus D & 20 \leq t \leq 39 \\ (B \wedge C) \vee(B \wedge D) \vee(C \wedge D) & 40 \leq t \leq 59 \\ B \oplus C \oplus D & 60 \leq t \leq 79 \\ \oplus=\text { fungsi XOR } & \end{cases}
$$

Konstanta kata yang digunakan pada SHA-1 yang disimbolkan secara berurutan dari $\mathrm{K}(0), \mathrm{K}(1), \ldots, \mathrm{K}(79)$ dalam bentuk hex seperti pada fungsi 02 berikut:

$$
K_{\mathrm{t}}=\left\{\begin{array}{cc}
\text { 5A827999 } & 0 \leq \mathrm{t} \leq 19 \\
\text { 6ED9EBA1 } & 20 \leq \mathrm{t} \leq 39 \\
\text { 8F1BBCDC } & 40 \leq \mathrm{t} \leq 59 \\
\text { CA62C1D6 } & 60 \leq \mathrm{t} \leq 79
\end{array}\right.
$$

Algoritma SHA-1 dapat diringkas sebagai berikut[6,9]:

a. Penghitungan menggunakan dua buffer dimana masing-masing buffer terdiri dari lima sebesar 32 bit kata dan urutan 80 juga sebesar 32 bit kata. Lima kata pertama pada buffer kata diberi nama $\mathrm{A}, \mathrm{B}, \mathrm{C}, \mathrm{D}$, E sedangkan lima kata kedua diberi nama $\mathrm{H}_{0}, \mathrm{H}_{1}, \mathrm{H}_{2}, \mathrm{H}_{3}$, dan $\mathrm{H}_{4}$. Kemudian pada 80 kata yang berurutan diberi nama $\mathrm{W}_{0}, \mathrm{~W}_{1}, \ldots, \mathrm{W}_{79}$ dan pada penghitungan ini juga memakai sebuah variabel sementara, TEMP.

b. Lakukan pengisian string, M dan kemudian kirimkan string tersebut ke dalam N 512 bit blok string, $\mathbf{M}^{(1)}, \mathrm{M}^{(2)}, \ldots, \mathrm{M}^{(\mathrm{n})}$. Caranya : 32 bit pertama dari blok string ditunjukkan $\mathrm{ke} \mathrm{M}_{0}{ }^{(\mathrm{i})}$, lalu 32 bit berikutnya adalah $\mathrm{M}_{1}{ }^{(\mathrm{i})}$ dan selanjutnya berlaku hingga $\mathrm{M}_{15}{ }^{(\mathrm{i})}$. 
c. Inisialisasi Nilai Hash (dalam bentuk hex) :
$\mathrm{H}_{0}=67452301 \quad \mathrm{H}_{3}=10325476$
$\mathrm{H}_{1}=$ EFCDAB89 $\mathrm{H}_{4}=\mathrm{C} 3 \mathrm{D} 2 \mathrm{E} 1 \mathrm{~F} 0$
$\mathrm{H}_{2}=98 \mathrm{BADCFE}$

d. Lakukan proses $\mathrm{M}_{1}, \mathrm{M}_{2}, \ldots, \mathrm{M}_{\mathrm{n}}$ dengan cara membagi $\mathrm{M}_{\mathrm{i}}$ ke dalam 16 kata $\mathrm{W}_{0}, \mathrm{~W}_{1}, \ldots, \mathrm{W}_{15}$ dimana $\mathrm{W}_{0}$ merupakan left most.

e. Hitung: For $\mathrm{t}=16$ to 79

$$
\mathrm{W}_{\mathrm{t}}=\mathrm{S}^{1}\left(\mathrm{~W}_{\mathrm{t}-3} \square \mathrm{W}_{\mathrm{t}-8} \square \mathrm{W}_{\mathrm{t}-14} \square \mathrm{W}_{\mathrm{t}-16}\right)
$$

f. Inisialisasi 5 variabel $\mathrm{A}, \mathrm{B}, \mathrm{C}, \mathrm{D}$, dan $\mathrm{E}$ dengan nilai Hash :

$\mathrm{A}=\mathrm{H}_{0} ; \mathrm{B}=\mathrm{H}_{1} ; \mathrm{C}=\mathrm{H}_{2} ; \mathrm{D}=\mathrm{H}_{3} ; \mathrm{E}=\mathrm{H}_{4}$.

Hitung: For $\mathrm{t}=0$ to 79

$\mathrm{TEMP}=\mathrm{S}^{5}(\mathrm{~A})+\mathrm{f}_{\mathrm{t}}(\mathrm{B}, \mathrm{C}, \mathrm{D})+\mathrm{E}+\mathrm{Wt}+\mathrm{Kt}$

$\mathrm{E}=\mathrm{D} ; \mathrm{D}=\mathrm{C} ; \mathrm{C}=\mathrm{S}^{30}(\mathrm{~B}) ; \mathrm{B}=\mathrm{A} ; \mathrm{A}=\mathrm{TEMP}$.

g. Hitung Nilai Hash:

$\mathrm{H}_{0}=\mathrm{H}_{0}+\mathrm{A} ; \mathrm{H}_{1}=\mathrm{H}_{1}+\mathrm{B}$;

$\mathrm{H}_{2}=\mathrm{H}_{2}+\mathrm{C} ; \mathrm{H}_{3}=\mathrm{H}_{3}+\mathrm{D}$;

$\mathrm{H}_{4}=\mathrm{H}_{4}+\mathrm{E}$.

Hasil dari message digest sebesar 160 bit dari string, M adalah: $\mathrm{H}_{0} \mathrm{H}_{1} \mathrm{H}_{2} \mathrm{H}_{3} \mathrm{H}_{4}$.

\subsection{Pemrograman Java}

Implementasi algoritma SHA-1 ini di buat dari bahasa pemrograman java yang akan digenarate menjadi sebuah library. Javaadalah bahasa pemrograman yang dapat dijalankan di berbagai komputer termasuk telepon genggam. Bahasa ini awalnya dibuat oleh James Gosling saat masih bergabung di Sun Microsystem saat ini merupakan bagian dari Oracle dan dirilis tahun 1995. Bahasa ini banyak mengadopsi sintaks $\mathrm{C}$ dan $\mathrm{C}++$ namun dengan sintaks model objek yang sederhana. Java merupakan bahasa pemrograman yang bersifat umum, dan secara khusus didesain untuk memanfaatkan dependensi implementasi seminimal mungkin. Karena fungsionaitasnya yang memungkinkan aplikasi Java mampu berjalan di beberapa platform sistem operasi yang berbeda $[4,8]$.

\section{METODE PENELITIAN}

\subsection{Jenis Penelitian}

Jenis Penelitian dalam penelitian ini adalah penelitian eksperimental yaitu membuat sebuah library, yang dapat digunakan sebagai sarana bagi programmer Java dalam membentuk/ membuat sebuah message digest dari suatu string.

\subsection{Rancangan Sistem}

Untuk lebih memahami sistem yang akan dibentuk, maka dibuatkan blok diagram pada gambar 2 berikut: 


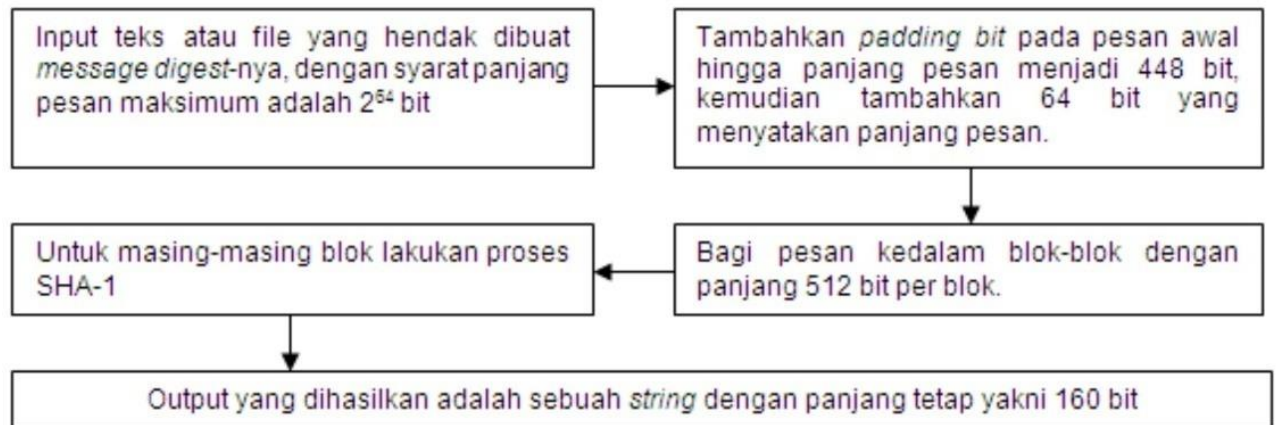

Gambar 2. Blok Diagram Secara Umum

Pada aplikasi yang akan dibuat, data yang diinput berupa data teks atau file yang akan dibuatkan message digest-nya dimana pesan memiliki panjang maksimum adalah $2^{64}$ bit, kemudian pada awal pesan ditambahkan padding bit sehingga panjang pesan menjadi 448 bit, dan tambahkan 64 bit yang menyatakan panjang pesan. Setelah itu pesan dibagi ke dalam blok-blok dengan panjang 512 bit per blok dan pada masing-masing blok dilakukan proses SHA-1. Setelah proses SHA-1 dilakukan pada masing-masing blok maka didapatkan hasil sebuah string dengan panjang tetap yakni 160 bit. Untuk mengetahui alir dokumen dari sistem bisa dilihat pada gambar 3 berikut:

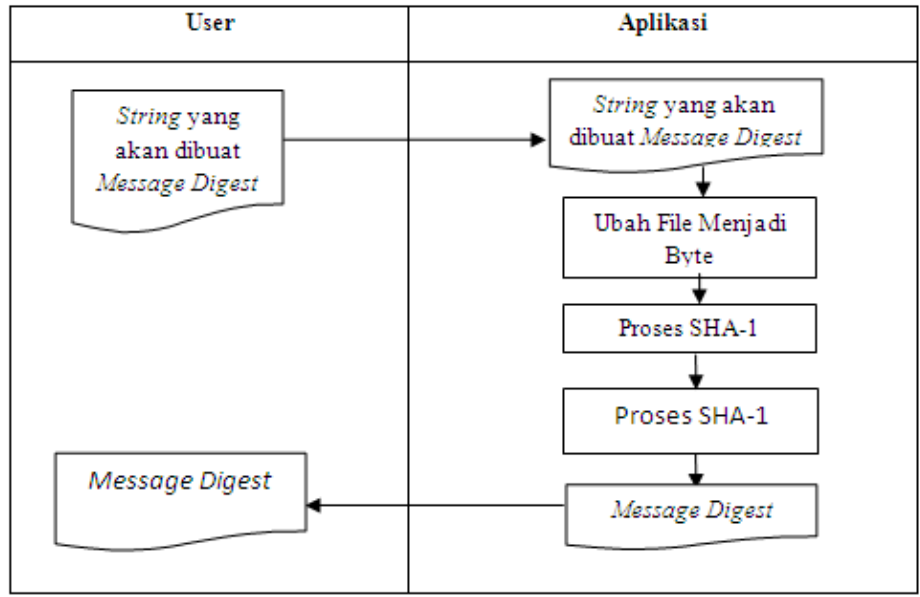

Gambar 3. Bagan Alir Dokumen SHA-1

\subsection{Rancangan Antarmuka Aplikasi}

\subsubsection{Form Utama}

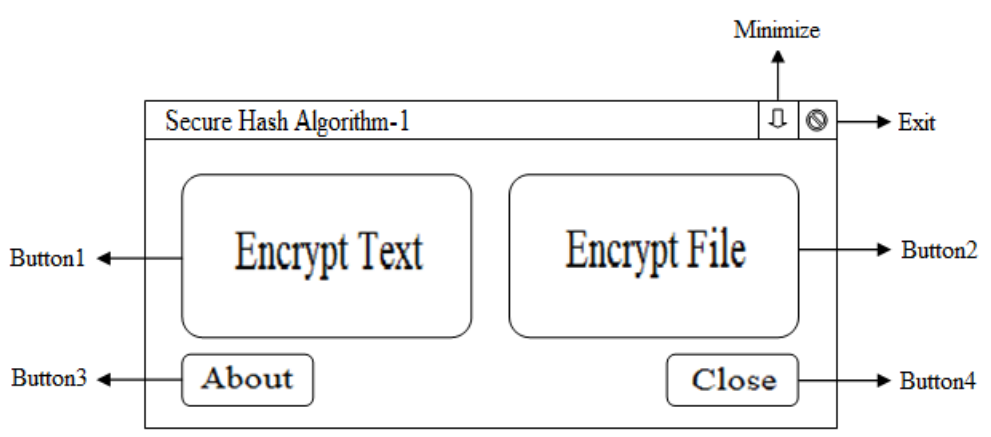

Gambar 4. Rancangan antarmuka Form Utama 
Citec Journal, Vol. 1, No. 1, November 2013 - Januari 2014

Form Utama seperti pada gambar 4 diatas merupakan antarmuka utama yang digunakan untuk menjalankan dua fungsi dari aplikasi Secure Hash Algorithm-1 (SHA-1) yaitu fungsi enkripsi teks dan enkripsi file.

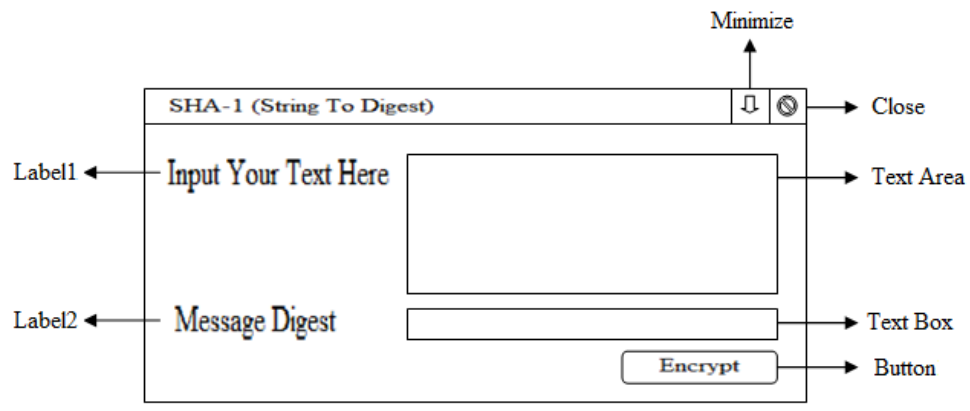

Gambar 5. Rancangan antarmuka Form Enkrip Teks

Form Enkrip Teks pada gambar 5 merupakan antarmuka yang digunakan untuk menjalankan fungsi enkripsi teks, dari suatu pesan berupa teks yang diiput menjadi suatu pesan digest.

\subsubsection{Form Enkrip File}

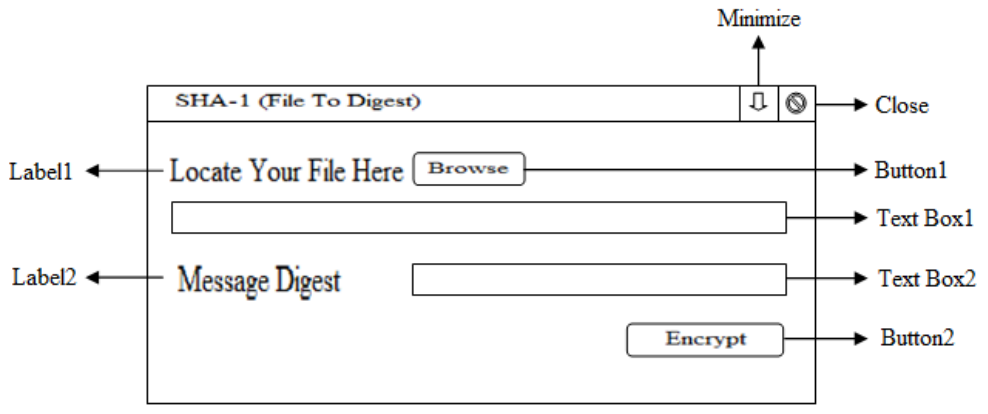

Gambar 6. Rancangan antarmuka Form Enkrip File

Form Enkrip File pada gambar 6 merupakan antarmuka yang digunakan untuk menjalankan fungsi enkripsi file, dari suatu pesan yang berada dalam sebuah file menjadi suatu pesan digest.

\section{HASIL PENELITIAN}

Secara umum proses enkripsi menggunakan algoritma SHA-1 dapat dijalankan atau diproses dengan dua proses input string yaitu string to digest dan file to digest, seperti yang terlihat pada gambar 7 berikut:

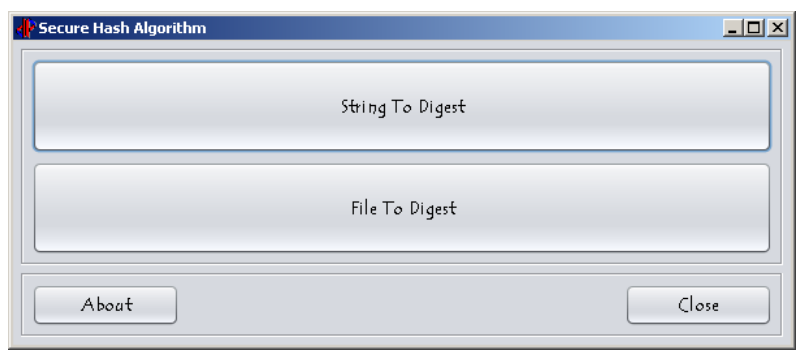

Gambar 7. Tampilan aplikasi utama 


\subsection{Hasil Enkripsi Teks (String to Digest)}

Hasil yang diperoleh dari proses enkripsi teks, berasal dari suatu sting yang diinput yang kemudian diproses dengan menggunakan algoritma SHA-1 dan menghasilkan suatu pesan digest yang memiliki panjang yang tetap yaitu 160 bit. Untuk lebih jelasnya bisa dilihat pada gambar 8 berikut:

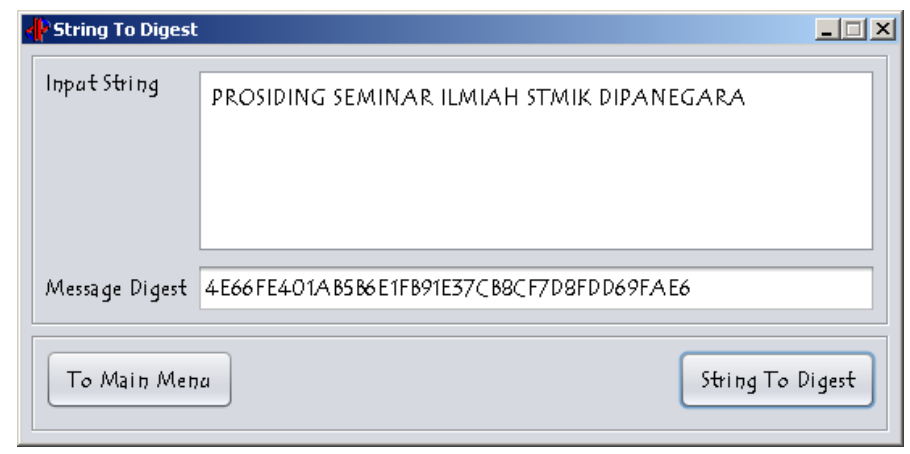

Gambar 8. Tampilan aplikasi utama

Pada gambar 8 diatas dengan input string PROSIDING SEMINAR ILMIAH STMIK DIPANEGARA akan menghasilkan panjang string 160 bit, dengan menggunakan metode SHA1 apabila terjadi perubahan sekecil apapun pada informasi yang diterima, dapat diketahui keasliannya melalui message digest. Misalnya akan diubah dengan menambahkan 1 (satu) karakter A diakhir string menjadi PROSIDING SEMINAR ILMIAH STMIK DIPANEGARAA hasil message digest akan berubah secara signifikan seperti pada gambar 9 berikut:

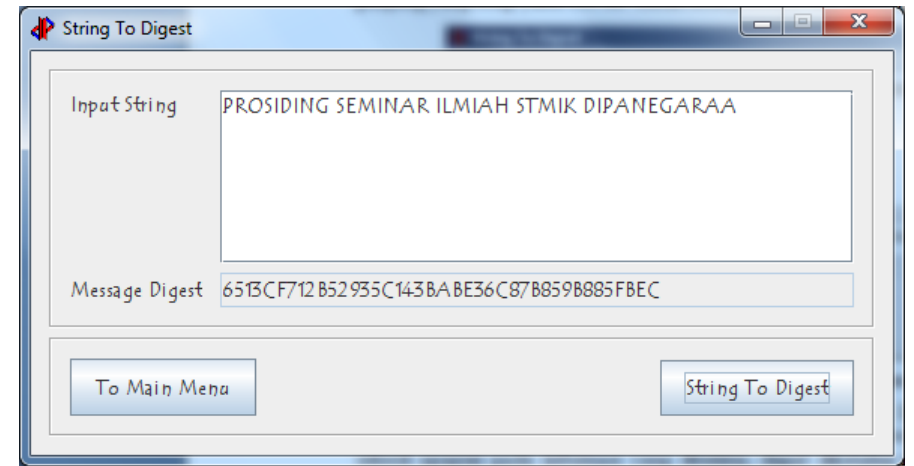

Gambar 9. Tampilan aplikasi utama

Dengan panjang string yang berbeda seperti pada gambar 8 dan gambar 9 akan tetap menghasilkan output string yang tetap yaitu 160 bit dan message digest akan berubah secara signifikan, hal ini akan berbeda dengan metode yang lain seperti md5 yang hanya menghasilkan panjang output 128 bit saja, ukuran digest yang dihasilkan MD5 lebih pendek ketimbang digest yang dihasilkan SHA-1. Digest MD5 juga cukup pendek untuk dipecahkan oleh serangan birthday attack dalam waktu relatif singkat [10].

\subsection{Hasil Enkripsi File (File to Digest)}

Hasil yang diperoleh dari proses enkripsi file, berasal dari suatu file yang dipilih dan kemudian diproses dengan menggunakan algoritma SHA-1 dan menghasilkan suatu pesan digest yang memiliki panjang yang tetap yaitu 160 bit. Untuk lebih jelasnya bisa dilihat pada gambar 10 dan gambar 11 berikut: 


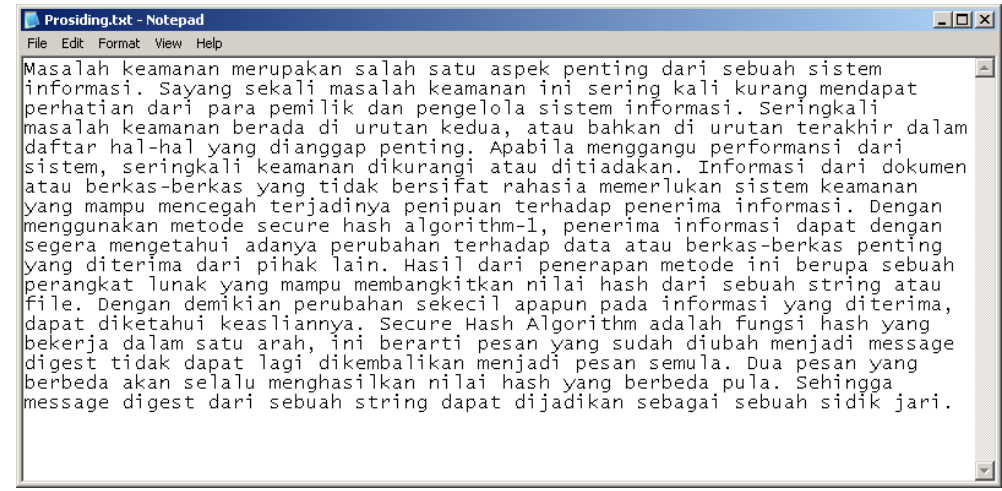

Gambar 10. Pesan yang berasal dari sebuah file

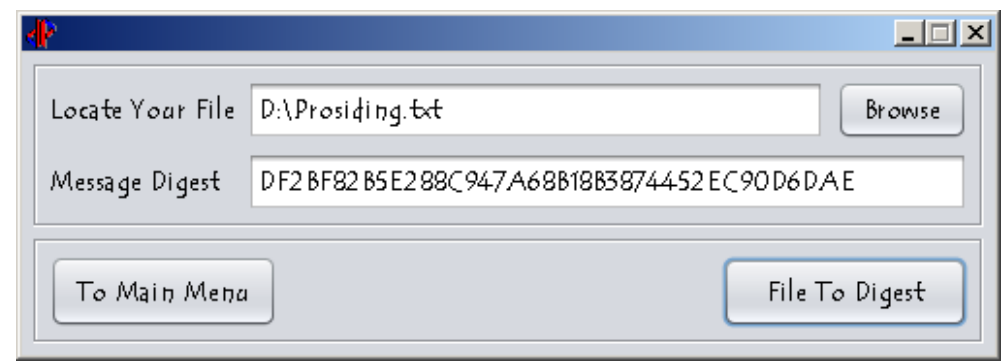

Gambar 11. Tampilan aplikasi utama

Pada gambar 10 adalah isi dari file Prosiding.txt yang dipilih melalui form seperti pada gambar 1. File to digest pada gambar 11 dengan file Prosiding.txt yang isi stringnya cukup panjang seperti pada gambar 11 akan tetap menghasilkan output 160 bit sama halnya dengan string to digest pada gambar 8 dan gambar 9 yang panjang stringnya lebih pendek dari file to digest.

\section{KESIMPULAN}

Hasil rancangan perangkat lunak dengan penerapan metode secure hash algorithm-1 dengan input panjang string yang berbeda akan menghasilkan output dengan panjang string tetap yaitu 160 bit. Penerapan metode secure hash algorithm-1 untuk keamanan data dalam rancangan ini dapat dibuat dalam bentuk library pada bahasa pemrograman java sehingga dapat langsung diimplementasikan untuk otentikasi atau pengamanan data maupun untuk pembuatan tanda tangan digital.

\section{SARAN}

Perangkat lunak dapat dikembangkan menjadi sebuah aplikasi text editor yang memberikan fasilitas tanda tangan digital (digital signature), sehingga diharapkan dapat digunakan oleh user dalam kehidupan sehari-hari seperti melakukan transaksi online. Perangkat lunak dapat dikembangkan dengan menambahkan kriptanalisis terhadap SHA-1 yang dibahas, sehingga dapat memberikan gambaran mengenai kemanan yang diberikan oleh SHA-1. 


\section{DAFTAR PUSTAKA}

[1] Ariyus, D., 2008, Pengantar Ilmu Kriptografi: Teori, Analisis, dan Implementasi, Penerbit Andi, Yogyakarta.

[2] 2005, Computer Security, Penerbit Andy, Yogyakarta

[3] , 2005, Kriptografi Keamanan Data dan Komunikasi, Graha Ilmu, Yogyakarta.

[4] Indrajani, Martin, 2007, Pemrograman Berbasis Objek dengan Bahasa Java, Elex Media Komputindo, Jakarta.

[5] Munir, R., 2006, Kriptografi, Penerbit Informatika, Bandung.

[6] Huda, M. 2009, Perkembangan Enkripsi Fungsi Hash pada SHA (Secure Hash Algorithm), Jurnal Ilmu Komputer dan Teknologi Informasi, Vol 3, No 2.

[7] Rahardjo, B., 2008, Keamanan Sistem Informasi, PT Insan Infonesia Bandung dan PT INDOCISC Jakarta.

[8] Fikri, R., Adam, I. F., Prakoso, I., 2005, Pemrograman Java, Andi, Yogyakarta.

[9] Alam, S., 2012, Otentikasi Nilai Hash Menggunakan Metode SHA, Prosiding Seminar Ilmiah Sistem Informasi dan Teknologi Informasi, Makassar.

[10] Wang W., Yu, H., 2005, How to Break MD5 and Other Hash Functions, EUROCYPT, hal 19-35. 